\title{
Micropropagation of licorice (Glycyrrhiza glabra L.) by using intermediate nodal explants
}

\author{
Aaqib Shaheen ${ }^{1,2}$, Munawar Ali ${ }^{2}$, Naveed Ahmad ${ }^{3}$, Yaser Hassan Dewir ${ }^{4,5^{*}}$, Salah El-Hendawy ${ }^{4,6}$, \\ and Ahmed M. Abd-El Gawad ${ }^{4,7}$
}

\begin{abstract}
${ }^{1}$ Henan University, School of Life Science, Cell Biology, Henan 475000, China.
${ }^{2}$ Qarshi Research International (Pvt) Ltd., Department of Biotechnology and Tissue Culture Laboratory (BTL), Hattar, District Haripur, Khyber Pakhtunkhwa Province 22610, Pakistan.

${ }_{3}^{3}$ Jilin Agricultural University, Department of Biotechnology, Changchun 130118, China.

${ }^{4}$ King Saud University, College of Food and Agriculture Sciences, Plant Production Department, P.O. Box 2460, Riyadh 11451,

Saudi Arabia. 'Corresponding author (ydewir@ksu.edu.sa).

${ }^{5}$ Kafrelsheikh University, Faculty of Agriculture, Department of Horticulture, Kafr El-Sheikh 33516, Egypt.

${ }^{6}$ Suez Canal University, Faculty of Agriculture, Agronomy Department, Ismailia 41522, Egypt.

${ }^{7}$ Mansoura University, Faculty of Science, Department of Botany, Mansoura 35516, Egypt.
\end{abstract}

Received: 3 November 2019; Accepted: 4 February 2020; doi:10.4067/S0718-58392020000300326

\begin{abstract}
Plant tissue culture techniques are useful for producing a large number of disease-free plant material. The aim of the present study was to determine the optimal nodal explant type (terminal, intermediate and basal) and cytokinins (6-benzyladenine and thidiazuron [TDZ] at concentrations of 0 to $3 \mathrm{mg} \mathrm{L}^{-1}$ ) for bud break and axillary shoot proliferation of Glycyrrhiza glabra L. The intermediate nodal explants were effective for the establishment of G. glabra aseptic culture when compared with terminal or basal nodal explants. The highest bud break $(89 \%)$ and axillary shoot proliferation (eight shoots) were observed when the intermediate nodal explants were cultured on MS medium supplemented with $2 \mathrm{mg} \mathrm{L}^{-1} \mathrm{TDZ}$ for $30 \mathrm{~d}$. The best rooting medium was MS medium supplemented with naphthalene acetic acid (NAA) compared with indole acetic acid; NAA at $6 \mathrm{mg} \mathrm{L}^{-1}$ yielded 78\% rooting and an average of 6.3 roots per plantlet. The regenerated plantlets were acclimatized, with a survival rate of $77.7 \%$, when transferred to ex vitro conditions and showed no morphological abnormalities. Thus, the high percentage of bud break and rate of shoot proliferation and successful acclimatization established a simple and efficient micropropagation of G. glabra.
\end{abstract}

Key words: Acclimatization, Fabaceae, rooting, shoot proliferation, tissue browning.

\section{INTRODUCTION}

Licorice (Glycyrrhiza glabra L.; Fabaceae) is a small perennial shrub capable of reaching a height of $2 \mathrm{~m}$. The leaves are multifoliate with 4-7 pairs of leaflets. The flowers are papilionaceous, spikes are lavender to violet in color, and the fruit is a compressed pod containing 3-5 seeds (Sofia and Walter, 2009). The roots and rhizomes, which have a cylindrical shape and diameter of $0.5-2.0 \mathrm{~cm}$, contain the principal active component glycyrrhizin, which is used for commercial purposes as a non-nutritional sweetening and flavoring agent in some candies and pharmaceuticals (Badkhane et al., 2014). Glycyrrhiza glabra has been reported to possess several medicinal properties such as antidiabetic, anti-inflammatory, antiulcer, antiallergic, anticarcinogenic, laxative, and antipyretic activities (Brown 1995; Badkhane et al., 2014).

Glycyrrhiza glabra is distributed from Southern Europe and Mediterranean region to Western China (Meena et al., 2010). The most important cultivated regions have been recorded mostly in the northern part of India, specifically in 
Punjab and sub-Himalayan tracts. It is also found in China, Italy, Russia, Spain, USA, and Germany; however, the frequency of G. glabra cultivation is higher in England, Spain, and Sicily. This plant occupies the land for an average period of 4-5 yr, with a maximal yield of $2 \mathrm{t}$ roots per acre (Vispute and Khopade, 2011). The demand for G. glabra in Indian pharmaceutical industries has been estimated to be $5000 \mathrm{t} \mathrm{yr}^{-1}$ (Tewari, 2000).

Conventional propagation of G. glabra is achieved through stolon division, but this method is slow with low progeny. Moreover, a large number of stock plants need to be maintained. Seeds are also used for propagation of G. glabra, but seed viability and germination are poor (Sawaengsak et al., 2011) and seedlings grow slowly (Brown, 1995). In vitro propagation can be used to ensure the supply of planting material for G. glabra cultivation as well as raw plant material to satisfy the increasing demands of the pharmaceutical industry. Previous studies on in vitro propagation of G. glabra mainly focused on indirect regeneration via callus formation (Mousa et al., 2006; Wongwicha et al., 2008; Fu et al., 2010; Sharma et al., 2010; Sarkar and Roy, 2014; 2015; Rathi et al., 2017). Direct regeneration of G. glabra has been achieved via axillary shoot proliferation using nodal explants (Shah and Dalal, 1980; Thengane et al., 1998; Mousa et al., 2006; Arya et al., 2009; Mehrotra et al., 2009; Yadav and Singh, 2012), in vitro stolon (Gupta et al., 2013), shoot tip culture, and apical and axillary buds (Kohjyouma et al., 1995; Sawaengsak et al., 2011). However, limited studies highlighted the influence of the type of nodal explants (position on the main stem) on culture establishment of G. glabra (Yadav and Singh, 2012). Composition of the media and content of plant growth regulators (PGRs) play a crucial role for optimal growth and morphogenesis of G. glabra (Jaiswal et al., 2017). Moreover, the success of in vitro regeneration and propagation depends on a series of stages with specific requirements for each step. In this study, we aimed to improve micropropagation of G. glabra through investigating the effects of various nodal explant positions within a shoot and combinations of PGRs on bud break and axillary shoot proliferation and the effects of different combinations of growing media on acclimatization and survival of the regenerated plantlets.

\section{MATERIALS AND METHODS}

\section{Plant material, surface disinfection, and establishment of aseptic culture}

The licorice (Glycyrrhiza glabra L.) plants were fully grown and maintained in the Department of Biotechnology and Tissue Culture Laboratory (BTL) of Qarshi Research International (Pvt) Ltd., Hattar, District Haripur, Khyber Pakhtunkhwa Province, Pakistan. Young, fresh and healthy growing shoots were collected and used as donor for initial explant material for initiation of aseptic culture. The young shoots were cut into nodal explants $(2-3 \mathrm{~cm})$ and classified as terminal ( $1^{\text {st }}$ and $2^{\text {nd }}$ node), intermediate ( $3^{\text {rd }}$ to $5^{\text {th }}$ node), and basal ( $6^{\text {th }}$ to $8^{\text {th }}$ node) nodal explants with relation to their position from the shoot apex (Figure 1). The explants were thoroughly washed under running tap water for $30 \mathrm{~min}$, treated with a few drops of a common detergent for $5 \mathrm{~min}$, and surface-disinfected in $10 \%(\mathrm{v} / \mathrm{v})$ commercial Clorox solution (5.2\% sodium hypochlorite, $\mathrm{NaOCl}$ ) containing 2-3 drops of Tween 20 (polyoxyethylene sorbitan monolaurate) for 10 min with continuous hand agitation. Then, the explants were washed three times with sterile distilled water, treated with $0.1 \%(\mathrm{w} / \mathrm{v}) \mathrm{HgCl}_{2}$ for $5 \mathrm{~min}$, and rinsed using sterile distilled water with occasional shaking. The nodal explants were cultured on MS medium (Murashige and Skoog, 1962) solidified with 1\% (w/v) agar and supplemented with $15 \mathrm{mg} \mathrm{L}^{-1}$ adenine sulfate. The aseptic and healthy nodal explants were used for the shoot proliferation experiment.

\section{Bud break and axillary shoot proliferation}

The nodal explants from the intermediate regions ( $3^{\text {rd }}$ to $5^{\text {th }}$ node) were cultured on MS medium supplemented with different concentrations of 6-benzylaminopurine (BAP; 0, 1, 2, and $3 \mathrm{mg} \mathrm{L}^{-1}$ ) and thidiazuron (TDZ; 0, 1, 2, and $3 \mathrm{mg} \mathrm{L}^{-1}$ ) or combination of BAP and TDZ at 1 and $2 \mathrm{mg} \mathrm{L}^{-1}$, respectively. Shoot growth and proliferation responses in terms of percentage of bud break, number of axillary shoots, and fresh and dry weight of whole explants were recorded after $30 \mathrm{~d}$ culture.

\section{In vitro rooting and culture conditions}

Axillary shoots of G. glabra $(4-5 \mathrm{~cm})$ were used for rooting in full-strength MS basal medium supplemented with indole acetic acid (IAA; 0, 2, 4, and $6 \mathrm{mg} \mathrm{L}^{-1}$ ) or naphthalene acetic acid (NAA; 0, 2, 4, and $6 \mathrm{mg} \mathrm{L}^{-1}$ ). Rooting percentage, time to root initiation, number of leaves, root length and number of roots, and plant height were recorded after $30 \mathrm{~d}$ culture. 
Figure 1. Type of nodal explants used for culture initiation of Glycyrrhiza glabra. Terminal node explant $\left(1^{\text {st }}\right.$ and $2^{\text {nd }}$ nodes), intermediate node explant ( $3^{\text {rd }}$ to $5^{\text {th }}$ nodes) and basal node explant ( $6^{\text {th }}$ to $8^{\text {th }}$ node).

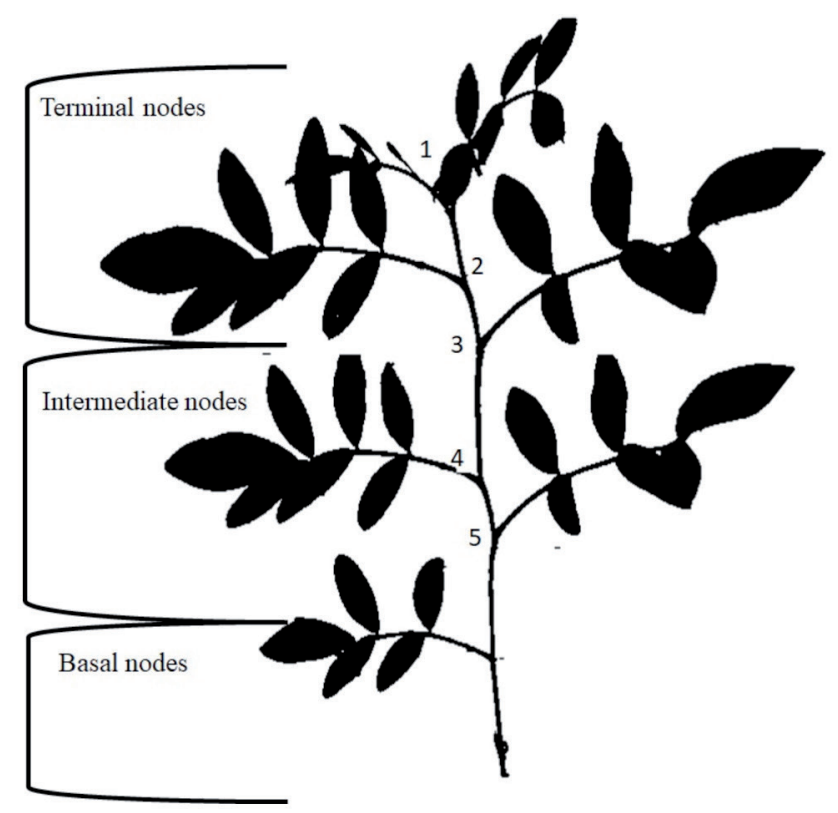

All media were supplemented with $3 \%(\mathrm{w} / \mathrm{v})$ sucrose and solidified with $0.8 \%(\mathrm{w} / \mathrm{v})$ agar-agar. The PGRs were added prior to autoclaving. The $\mathrm{pH}$ of the medium was adjusted to 5.8 before autoclaving at $121{ }^{\circ} \mathrm{C}$ for $15 \mathrm{~min}$. The cultures were incubated at $25 \pm 2{ }^{\circ} \mathrm{C}$ under a $16: 8 \mathrm{~h}$ photoperiod maintained using cool-white fluorescent lights at $35 \mu \mathrm{mol} \mathrm{m}^{-2} \mathrm{~s}^{-1}$ photosynthetic photon flux density (PPFD).

\section{Acclimatization of the regenerated plantlet}

The regenerated plantlets were transferred to pots filled with different combinations of growing media, i.e., clay soil, sand, silt, and peat moss (1:1 v/v; Table 1$)$. The plantlets were maintained at high humidity by covering with transparent polythene bags to ensure high humidity. Plantlets were grown for $20 \mathrm{~d}$ in controlled environment growth chambers. The environment in the growth chamber was adjusted to $25 \pm 2{ }^{\circ} \mathrm{C}, 60 \%-70 \% \mathrm{RH}$, and a 16:8 h photoperiod maintained using white fluorescent tubes (Phillips Maxlife, Phillips, Pakistan) at $42 \mu \mathrm{mol} \mathrm{m}{ }^{-2} \mathrm{~s}^{-1}$ PPFD. Partially acclimatized plantlets with 4-5 primary leaves were then transferred to larger earthen pots $(15 \mathrm{~cm}$ in diameter) containing peat moss and soil $(1: 1 \mathrm{v} / \mathrm{v})$ for improved establishment of the plantlets for the next $20 \mathrm{~d}$. After $40 \mathrm{~d}$ acclimatization, plantlets grew well in potted soil and peat moss $(3: 1 \mathrm{v} / \mathrm{v})$ in greenhouse conditions.

Table 1. Effect of different growing media on survival rate of micropropagated Glycyrrhiza glabra plantlets after $40 \mathrm{~d}$ of acclimatization.

\begin{tabular}{lc}
\hline Growing media & Survival \\
\hline$(1: 1 \mathrm{v} / \mathrm{v})$ & $\%$ \\
Garden soil & $22.2 \mathrm{c}$ \\
Soil + Silt & $22.2 \mathrm{c}$ \\
Soil + Sand & $33.3 \mathrm{c}$ \\
Silt + Sand & $33.3 \mathrm{c}$ \\
Soil + Silt + Sand & $11.1 \mathrm{~d}$ \\
Peat moss & $44.4 \mathrm{~b}$ \\
Peat moss + Soil & $77.7 \mathrm{a}$ \\
Peat moss + Soil + Silt + Sand & $44.4 \mathrm{~b}$ \\
\hline
\end{tabular}

Values followed by the same letter in the same column are nonsignificantly different according to Tukey's test $(\mathrm{P} \leq 0.05)$. 


\section{Experimental design and statistical analysis}

The experiments were performed using a completely randomized design with three replicates in each treatment and there were nine explants in each treatment. Data expressed as percentages were arcsine-transformed before the analysis (Compton, 1994). All data were subjected to Tukey's multiple range test using SAS program (Version 6.12; SAS Institute, Cary, North Carolina, USA).

\section{RESULTS AND DISCUSSION}

\section{Culture establishment of G. glabra}

Different positions of the nodal explants showed varied responses for contamination and tissue browning. The high contamination rate $(90 \%)$ was a serious problem for use of basal nodal explants (Table 2). Several attempts for surface disinfection of these explants by using different disinfectants for longer durations resulted in damage of the explants. Yadav and Singh (2012) reported similar findings in which basal nodal explants $\left(7^{\text {th }}\right.$ to $10^{\text {th }}$ nodes) showed serious contamination. Tissue browning was also another problem during the establishment of G. glabra aseptic culture, and it was apparent in the terminal node culture. Early study by Shah and Dalal (1980) reported that browning of G. glabra nodes and base of the petiole occurred after few days of culture. Conversely, terminal and axillary buds of G. glabra did not show browning symptoms during culture establishment (Thengane et al., 1998). Tissue browning occurs because of the accumulation and subsequent oxidation of phenolic compounds in the tissue and culture medium (Krishna et al., 2008; Uchendu et al., 2011). Oxidative browning causes slow growth and eventually leads to cell/tissue or plant death (Krishna et al., 2008; Dewir et al., 2018a) and has been reported to hinder the establishment of cultures of G. glabra (Shah and Dalal, 1980). Several other plant species such as Arbutus unedo (El-Mahrouk et al., 2010) and Conocarpus erectus (Dewir et al., 2018a) were also affected by oxidative browning. The intermediate nodal explants proved effective for the establishment of G. glabra aseptic culture when compared with the terminal as well as basal nodal explants; therefore, they were used for axillary shoot proliferation.

\section{Bud break and axillary shoot proliferation}

Supplementation of the medium with cytokinins (BAP or TDZ) alone or in combination affected the percentage of bud break, shoot proliferation, and growth of the nodal explants (Table 3). The nodal explants cultured on medium without cytokinins showed only $22 \%$ bud break and two axillary shoots. The highest bud break (89\%), number of shoots (8), fresh weight $(2.03 \mathrm{~g})$, and dry weight $(0.26 \mathrm{~g})$ were obtained from the nodal explants cultured on the medium supplemented with $2 \mathrm{mg} \mathrm{L}^{-1} \mathrm{TDZ}$ (Figure 2A and 2B). Lower concentration of TDZ $\left(1 \mathrm{mg} \mathrm{L}^{-1}\right)$ also resulted in high shoot proliferation and growth but induced a significantly low bud break (67\%) when compared with $2 \mathrm{mg} \mathrm{L}^{-1} \mathrm{TDZ}$. High TDZ concentration (3 $\mathrm{mg} \mathrm{L}^{-1}$ ) significantly reduced the percentage of bud break and shoot proliferation of the nodal explants. The addition of 2 $\mathrm{mg} \mathrm{L}^{-1} \mathrm{BAP}$ to the medium stimulated $67 \%$ bud break and shoot proliferation (5.7 shoots) when compared with the control treatment. In general, TDZ was more effective than BAP for bud break and shoot proliferation of the nodal explants. Antagonistically, low values of bud break and shoot proliferation were obtained when BAP was combined with TDZ. Previous studies have reported low rates of axillary shoot proliferation despite high bud break percentage in licorice. A hundred percent bud break and 1-2 elongated shoots were reported by Thengane et al. (1998) on MS medium containing $2 \mathrm{mg} \mathrm{L}^{-1}$ BAP within $20 \mathrm{~d}$ incubation. Similarly, Arya et al. (2009) reported 85\%-90\% bud break and only 1-2 shoots on a medium supplemented with $2 \mathrm{mg} \mathrm{L}^{-1}$ BAP within $3 \mathrm{wk}$ in all aseptic cultures. Yadav and Singh (2012) reported 86.6\%

Table 2. Effect of type of nodal explants on percentages of contamination and browning during culture initiation of Glycyrrhiza glabra after $15 \mathrm{~d}$ in culture.

\begin{tabular}{lcc}
\hline Type of nodal explants & Contamination & Browning \\
\hline & $\%$ & $\%$ \\
Terminal $\left(1^{\text {st }}\right.$ and $2^{\text {nd }}$ node $)$ & $20.0 \mathrm{c}$ & $50.0 \mathrm{a}$ \\
Intermediate $\left(3^{\text {rd }}\right.$ to $5^{\text {th }}$ node $)$ & $40.0 \mathrm{~b}$ & $0.0 \mathrm{~b}$ \\
Basal $\left(6^{\text {th }}\right.$ to $8^{\text {th }}$ node $)$ & $90.0 \mathrm{a}$ & $0.0 \mathrm{~b}$
\end{tabular}

Values followed by the same letter in the same column are nonsignificantly different according to Tukey's test $(\mathrm{P} \leq 0.05)$. 
bud break and a maximum of three shoots by using MS medium containing $2 \mathrm{mg} \mathrm{L}^{-1} \mathrm{BA}$ and $0.5 \mathrm{mg} \mathrm{L}^{-1} \mathrm{NAA}$ after 3 wk in culture. Shah and Dalal (1980) reported four axillary buds per nodal explant on modified MS medium within 15-20 $\mathrm{d}$ of culture. In the present study, the use of $2 \mathrm{mg} \mathrm{L}^{-1} \mathrm{TDZ}$ enhanced bud break (90\%) and produced the highest number of axillary shoots (eight shoots). These results for bud break and rate of axillary shoot proliferation are higher than those reported in previous studies (Shah and Dalal, 1980; Thengane et al., 1998; Arya et al., 2009; Yadav and Singh, 2012), in which they mainly used BAP. Several developmental patterns in plant tissue culture were attributed to the regulatory role of TDZ in the biosynthesis and accumulation of endogenous hormones (Ahmad and Faisal, 2018; Dewir et al., 2018b).

Table 3. Effect of cytokinins type and concentrations on axillary shoot proliferation from mature nodal explants of Glycyrrhiza glabra after $30 \mathrm{~d}$ in culture.

\begin{tabular}{|c|c|c|c|c|c|}
\hline & Cytokinins & Bud break & Shoots & Fresh weight & Dry weight \\
\hline & $\mathrm{mg} \mathrm{L}^{-1}$ & $\%$ & $\mathrm{Nr}$ explant ${ }^{-1}$ & g explant ${ }^{-1}$ & g explant $^{-1}$ \\
\hline MS basal medium (control) & $22.0 \mathrm{e}$ & $2.0 \mathrm{~d}$ & $0.86 \mathrm{e}$ & $0.10 \mathrm{c}$ & \\
\hline \multirow[t]{3}{*}{ BAP } & 1 & $33.0 \mathrm{~d}$ & $3.0 \mathrm{~cd}$ & $0.95 \mathrm{de}$ & $0.17 b c$ \\
\hline & 2 & $67.0 \mathrm{~b}$ & $5.7 \mathrm{~b}$ & $1.96 \mathrm{a}$ & $0.24 \mathrm{a}$ \\
\hline & 3 & $33.0 \mathrm{~d}$ & $3.7 \mathrm{c}$ & $1.12 \mathrm{~d}$ & $0.16 b c$ \\
\hline \multirow[t]{3}{*}{ TDZ } & 1 & $67.0 \mathrm{~b}$ & $7.7 \mathrm{a}$ & $1.97 \mathrm{a}$ & $0.24 \mathrm{a}$ \\
\hline & 2 & $89.0 \mathrm{a}$ & $8.0 \mathrm{a}$ & $2.00 \mathrm{a}$ & $0.26 \mathrm{a}$ \\
\hline & $3^{1}$ & $33.0 \mathrm{~d}$ & $5.3 b$ & $1.50 \mathrm{c}$ & $0.15 \mathrm{c}$ \\
\hline \multirow[t]{2}{*}{$\mathrm{BAP}+\mathrm{TDZ}$} & $1+1$ & $33.0 \mathrm{~d}$ & $3.3 \mathrm{~cd}$ & $1.03 \mathrm{de}$ & $0.16 b c$ \\
\hline & $2+2$ & $56.0 \mathrm{c}$ & $5.3 \mathrm{~b}$ & $1.77 \mathrm{~b}$ & $0.19 \mathrm{~b}$ \\
\hline
\end{tabular}

Values followed by the same letter in the same column are nonsignificantly different according to Tukey's test $(\mathrm{P} \leq 0.05)$.

BAP: 6-Benzylaminopurine; TDZ: thidiazuron.

Figure 2. Micropropagation of Glycyrrhiza glabra. Shoot proliferation on MS (Murashige and Skoog) medium supplemented with $2 \mathrm{mg} \mathrm{L}^{-1}$ thidiazuron after $30 \mathrm{~d}$ in culture (A and B), in vitro rooting of proliferated shoots on MS medium supplemented with $6 \mathrm{mg} \mathrm{L}^{-1}$ naphthalene acetic acid after $30 \mathrm{~d}$ in culture (C and D), micropropagated plantlet grown in peat moss + soil $(1: 1 \mathrm{v} / \mathrm{v})$ after $40 \mathrm{~d}$ in acclimatization $(E)$, fully acclimatized micropropagated plant after 100 d of acclimatization $(\mathbf{F})$.
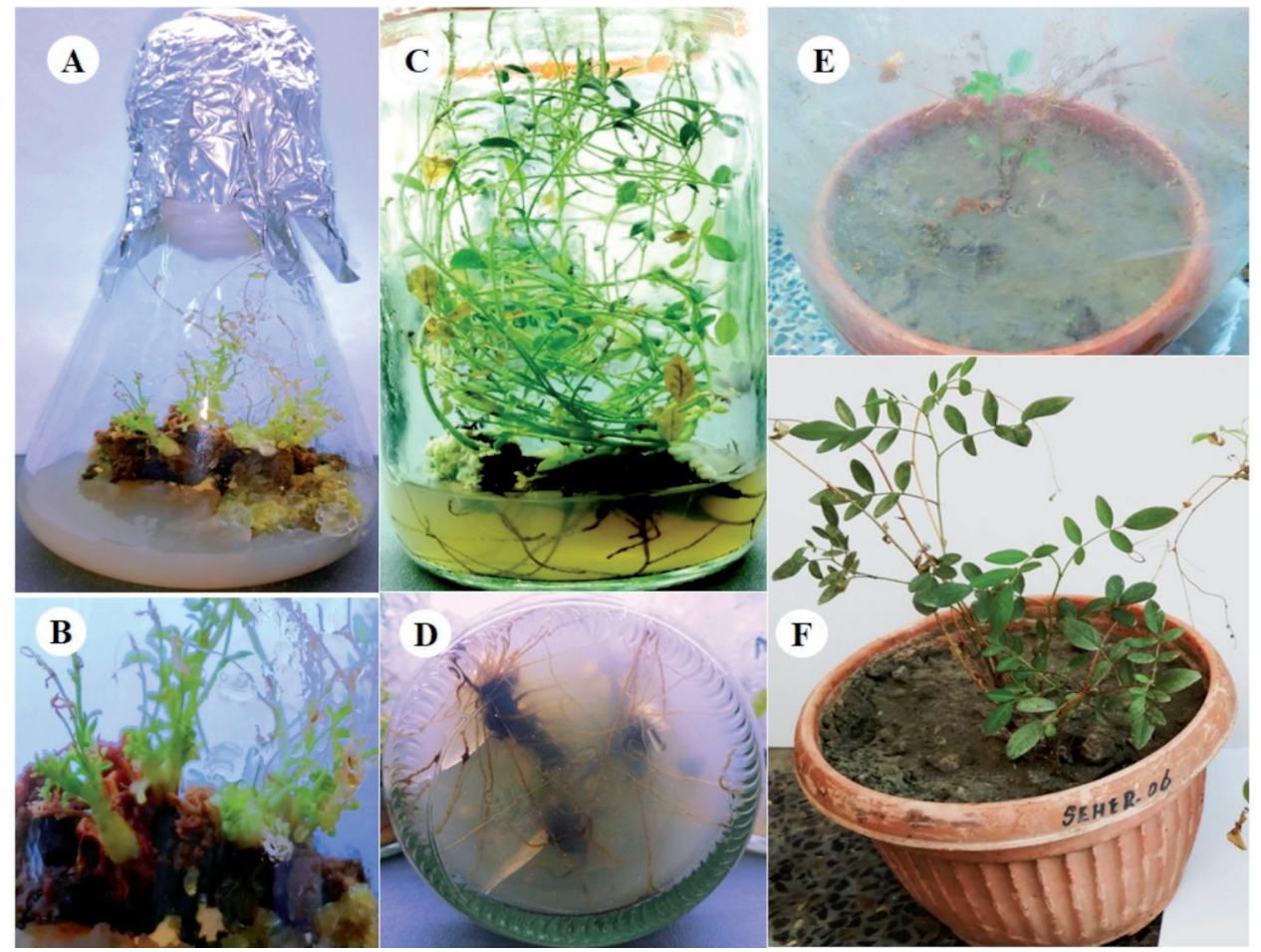
Despite the efficiency of TDZ in the present study, axillary shoot proliferation was associated with callus formation at the basal parts of the nodal explant, but these calluses turned brown and did not regenerate shoots. Moreover, high TDZ concentration ( $\left.3 \mathrm{mg} \mathrm{L}^{-1}\right)$ reduced the percentage of bud break (33\%). Several detrimental effects, including callus formation and inhibition of shoot proliferation, have been reported to be associated with the use of high TDZ concentrations (Dewir et al., 2018b).

\section{In vitro rooting of $G$. glabra microshoots}

MS media supplemented with all concentrations of IAA and NAA induced rooting of G. glabra microshoots (Table 4). Among the various concentrations of IAA and NAA tested, $6 \mathrm{mg} \mathrm{L}^{-1} \mathrm{NAA}$ resulted in the highest rooting (78\%), shortest time to root initiation (14 d), number of roots (3.3), root length $(6.3 \mathrm{~cm})$, number of leaves (8.3), and plant height $(11 \mathrm{~cm})$. The number of days required for root initiation decreased with increased auxin concentrations. However, NAA proved superior to IAA for rooting of G. glabra microshoots. No rooting was observed on MS media without auxins. Previous studies have indicated that auxins are indispensable for rooting of G. glabra. Microshoots and no rooting were observed in medium without auxins (Thengane et al., 1998; Yadav and Singh, 2012). Moreover, root initiation in microshoots of $G$. glabra takes a considerably long time, i.e., $16.7 \mathrm{~d}\left(1 / 2 \mathrm{MS}+1 \mathrm{mg} \mathrm{L}^{-1}\right.$ IAA; Yadav and Singh 2012). Kohjyouma et al. (1995) observed root formation (77.8\%) in G. glabra microshoots after $80 \mathrm{~d}$ in a rooting medium containing $0.05-0.10 \mathrm{mg} \mathrm{L}^{-1} \mathrm{NAA}$. High auxin concentrations are favorable for rooting of $\mathrm{G}$. glabra microshoots, i.e., $5 \mathrm{mg} \mathrm{L}^{-1}$ IAA or indole butyric acid (IBA) (Sawaengsak et al., 2011) and $3 \mathrm{mg} \mathrm{L}^{-1}$ IAA (Sarkar and Roy, 2014). Our results confirm previous findings in which a high auxin concentration (6 mg L ${ }^{-1}$ NAA) produced thick and healthy roots (Figure 2C and 2D); moreover, low auxin concentrations favored caulogenesis. Yadav and Singh (2012) reported that despite effective rooting (100\%) at $1 \mathrm{mg} \mathrm{L}^{-1}$ IAA, calli were formed at the basal base of G. glabra microshoots. In contrast, rooting of G. glabra microshoots was achieved using low auxin concentration, i.e., $0.1 \mathrm{mg} \mathrm{L}^{-1} \mathrm{NAA}$ (Shah and Dalal, 1980) and $0.01 \mathrm{mg} \mathrm{L}^{-1} \mathrm{NAA}$ (Gupta et al., 2013). It seems that the rootability of G. glabra microshoots is influenced by the PGR type and concentration applied during the shoot multiplication stage. The carry-over effects of cytokinins on rootability have been demonstrated in several plant species that belong to the family Fabaceae (Dewir et al., 2016).

\section{Acclimatization and survival of G. glabra plantlets}

Various mixtures of growing media significantly influenced the survival rate of the G. glabra regenerated plantlets (Table 1). Among the eight potting mixtures used, the highest survival rate $(77.7 \%)$ was observed with a mixture of peat moss and clay soil $(1: 1 \mathrm{v} / \mathrm{v})$, and the lowest survival rate $(11.1 \%)$ was detected with a mixture of soil, silt, and sand (1:1:1 $\mathrm{v} / \mathrm{v} / \mathrm{v})$. All other mixtures yielded varied survival rates. These differences in the survival rates of G. glabra plantlets are mainly attributed to the physical properties of the growing media. Peat moss is a commonly used growing medium because of its nutrient availability and water-holding capacity. It holds nutrients readily taken up by plants and improves growth rate of plants (Atiyeh et al., 2000). However, mixing peat moss with other media could improve the aeration for the root zone, resulting in high survival of plants. Several mixtures have been reported for acclimatization of G. glabra

Table 4. Effect of auxins concentrations on rooting of Glycyrrhiza glabra after $30 \mathrm{~d}$ in culture.

\begin{tabular}{lccccccc}
\hline & Auxins & Rooting & $\begin{array}{c}\text { Time to root } \\
\text { initiation }\end{array}$ & Leaves & $\begin{array}{c}\text { Root } \\
\text { length }\end{array}$ & Roots & $\begin{array}{c}\text { Plant } \\
\text { height }\end{array}$ \\
\hline \multirow{3}{*}{ MS basal medium (control) } & $\mathrm{mg} \mathrm{L}^{-1}$ & $\%$ & $\mathrm{~d}$ & Nr explant & $\mathrm{cm}$ & Nr explant $^{-1}$ & $\mathrm{~cm}^{-1}$ \\
IAA & $0 \mathrm{c}$ & $0.0 \mathrm{f}$ & $2.0 \mathrm{~d}$ & $0.0 \mathrm{~d}$ & $0.0 \mathrm{c}$ & $3.8 \mathrm{~d}$ & \\
& 2 & $33 \mathrm{~b}$ & $20.0 \mathrm{c}$ & $2.0 \mathrm{~d}$ & $2.6 \mathrm{c}$ & $1.0 \mathrm{~b}$ & $7.3 \mathrm{~b}$ \\
& 4 & $33 \mathrm{~b}$ & $24.0 \mathrm{a}$ & $2.7 \mathrm{~cd}$ & $2.6 \mathrm{c}$ & $1.5 \mathrm{~b}$ & $7.3 \mathrm{~b}$ \\
NAA & 6 & $44 \mathrm{~b}$ & $15.0 \mathrm{~d}$ & $3.7 \mathrm{bc}$ & $3.0 \mathrm{bc}$ & $1.7 \mathrm{~b}$ & $6.0 \mathrm{c}$ \\
& 2 & $33 \mathrm{~b}$ & $23.0 \mathrm{~b}$ & $3.3 \mathrm{c}$ & $3.0 \mathrm{bc}$ & $1.7 \mathrm{~b}$ & $6.0 \mathrm{c}$ \\
& 4 & $33 \mathrm{~b}$ & $23.3 \mathrm{ab}$ & $4.7 \mathrm{~b}$ & $3.7 \mathrm{~b}$ & $1.7 \mathrm{~b}$ & $7.0 \mathrm{bc}$ \\
& 6 & $78 \mathrm{a}$ & $14.0 \mathrm{e}$ & $8.3 \mathrm{a}$ & $6.3 \mathrm{a}$ & $3.3 \mathrm{a}$ & $11.0 \mathrm{a}$ \\
\hline
\end{tabular}

Values followed by the same letter in the same column are nonsignificantly different according to Tukey's test $(\mathrm{P} \leq 0.05)$.

IAA: Indole acetic acid; NAA: Naphthalene acetic acid. 
plantlets, including a mixture of sand, soil, and farmyard manure (1:1:1 v/v/v; Sharma et al., 2010) and earthen pots containing sand, soil, and farmyard manure (1:1:1 v/v/v; Mehrotra et al., 2009). Thengane et al. (1998) reported that direct transfer of G. glabra plantlets to the soil caused wilting and mortality. Therefore, the plantlets were grown in tap water for $1 \mathrm{wk}$ and then transferred to pots containing a sterilized sand and soil mixture $(1: 1: \mathrm{v} / \mathrm{v})$.

\section{CONCLUSIONS}

We conclude that the intermediate nodes are optimal explants for the culture establishment of Glycyrrhiza glabra. Thidiazuron proved be effective plant growth regulator for obtaining the highest bud break and axillary shoot proliferation. A mixture of peat moss and clay soil $(1: 1 \mathrm{v} / \mathrm{v})$ was optimal substrate for acclimatization of G. glabra plantlets.

\section{ACKNOWLEDGEMENTS}

The authors extend their appreciation to the Deanship of Scientific Research at King Saud University for funding this work through research group NO (RGP-1438-012) and to the Researchers Support \& Services Unit (RSSU) for their technical support.

\section{REFERENCES}

Ahmad, N., and Faisal, M. (eds.) 2018. Thidiazuron: From urea derivative to plant growth regulator. Springer, Singapore. Arya, S., Rathi, N., and Arya, I.D. 2009. Micropropagation protocol for Glycyrrhiza glabra L. Phytomorphology 59:71-76.

Atiyeh, M.R., Subler, S., Edwards, C.A., Bachman, G., Metzger, J.D., and Shuster, W. 2000. Effects of vermicomposts and composts on plant growth in horticultural container media and soil. Pedobiologia 44:579-590.

Badkhane, Y., Yadav, A.S., Bajaj, A., Sharma, A.K., and Raghuwanshi, D.K. 2014. Glycyrrhiza glabra L. a miracle medicinal herb. Indo American Journal of Pharmaceutical Research 4:5808-5816.

Brown, D. 1995. The Herb National Society of America Encyclopedia of herbs and their uses. Dorling Kindersley Publishing, New York, USA.

Compton, M.E. 1994. Statistical methods suitable for the analysis of plant tissue culture data. Plant Cell, Tissue and Organ Culture 37:217-242.

Dewir, Y.H., Aldubai, A.A., El-Hendawy, S., Alsadon, A.A., Seliem, M.K., and Naidoo, Y. 2018a. Micropropagation of buttonwood tree (Conocarpus erectus) through axillary shoot proliferation. HortScience 53:687-691.

Dewir, Y.H., Murthy, H.N., Ammar, M.H., Alghamdi, S.S., Al-Suhaibani, N.A., Alsadon, A.A., et al. 2016. In vitro rooting of leguminous plants: difficulties, alternatives, and strategies for improvement. Horticulture Environment and Biotechnology 57:311-322.

Dewir, Y.H., Nurmansyah, Naidoo, Y., and Teixeira da Silva, J.A. 2018b. Thidiazuron-induced abnormalities in plant tissue cultures. Plant Cell Reports 37:1451-1470.

El-Mahrouk, M.E., Dewir, Y.H., and Omar, A.M.K. 2010. In vitro propagation of adult strawberry tree (Arbutus unedo L.) through adventitious shoots and somatic embryogenesis. Propagation of Ornamental Plants 10:93-98.

Fu, C., Lei, C., Gan, L., Li, M., Yang, Y., and Yu, L. 2010. Optimization of embryogenic-callus induction and embryogenesis of Glycyrrhiza glabra. African Journal of Biotechnology 9:5823-5829.

Gupta, S., Pandotra, P., Gupta, A.P., Verma, M.K., Ahuja, A., and Vishwakarma, R.A. 2013. Direct rhizogenesis, in vitro stolon proliferation and high-throughput regeneration of plantlets in Glycyrrhiza glabra. Acta Physiologiae Plantarum 35:2699-2705.

Jaiswal, N., Verma, Y., and Misra, P. 2017. Micropropagation and in vitro elicitation of licorice (Glycyrrhiza spp.) In Vitro Cellular and Developmental Biology - Plant 53:145-166.

Kohjyouma, M., Kohda, H., Tani, N., Ashida, K., Sugino, M., Yamamoto, A., et al. 1995. In-vitro propagation from axillary buds of Glycyrrhiza glabra L. Plant Tissue Culture Letters 12:145-149.

Krishna, H., Sairam, R.K., Singh, S.K., Patel, V.B., Sharma, R.R., Grover, M., et al. 2008. Mango explant browning: Effect of ontogenic age, mycorrhization and pre-treatments. Scientia Horticulturae 118:132-138.

Meena, A.K., Arjun, S., Kiran, S., Suman, K., and Rao, M.M. 2010. Physicochemical and preliminary phytochemical studies on the rhizomes of Glycyrrhiza glabra Linn. International Journal of Pharmacy and Pharmaceutical Sciences 2(Suppl 2):48-50.

Mehrotra, S., Bhartendu, N.M., and Kukreja, A.K. 2009. Efficiency of liquid system for mass multiplication of Glycyrrhiza glabra and evaluation of genetic fidelity of micropropagated plants. International Journal of Biotechnology and Biochemistry 5:157-169. 
Mousa, N., Siaguru, P., Wiryowidagdo, S., and Wagih, M.E. 2006. Rapid clonal propagation of licorice (Glycyrrhiza glabra) by in vitro shoot culture. Sugar Technology 8:292-298.

Murashige, T., and Skoog, F. 1962. A revised medium for rapid growth and bio assays with tobacco tissue cultures. Physiologia Plantarum 15:473-497.

Rathi, N., Dwivedi, S., Rao, N.N., Arya, S., and Arya, I.D. 2017. Optimization of media constituents for regeneration via callus cultures of Glycyrrhiza glabra L. an endangered plant. Biochemical and Cellular Archives 17:389-398.

Sarkar, M., and Roy, S.C. 2014. Rapid scale micropropagation of Glycyrrhiza glabra L. (Leguminoseae) a valuable medicinal herb. International Journal of Scientific Research 3:20-22.

Sarkar, M., and Roy, S.C. 2015. Influences of medium parameters on somatic embryogenesis from leaf explants of Glycyrrhiza glabra. Indian Journal of Scientific Research 10:63-67.

Sawaengsak, W., Saisavoey, T., Chuntaratin,P., and Karnchanatat, A. 2011. Micropropagation of the medicinal herb Glycyrrhiza glabra L., through shoot tip explant culture and glycyrrhizin detection. International Research Journal of Plant Science 2:129-136.

Shah, R.R., and Dalal, K.C. 1980. In vitro multiplication of Glycyrrhiza. Current Science 49:69-71.

Sharma, A.K., Yadav, A.S., Raghuwanshi, D.K., Firdous, A.M., Lone, S.A., and Rai, A.K. 2010. An improved protocol for rapid, efficient and high frequency regeneration of Glycyrrhiza glabra L. Asian Journal of Experimental Sciences 24:1-7.

Sofia, H.N., and Walter, T.M. 2009. Review of Glycyrrhiza glabra, Linn. Siddha Papers. Medical Journal 2:1-7.

Tewari, D.N. 2000. Report of the task force on conservation and sustainable use of medicinal plants. Available at http://planningcommission.gov.in. Planning Commission, Government of India, New Delhi, India.

Thengane, S.R., Kulkarni, D.K., and Krishnamurthy, K.V. 1998. Micropropagation of licorice (Glycyrrhiza glabra L.) through shoot tip and nodal cultures. In Vitro Cellular and Developmental Biology - Plant 34:331-334.

Uchendu, E.E., Paliyath, G., Brown, D.C., and Saxena, P.K. 2011. In vitro propagation of North American ginseng (Panax quinquefolius L.) In Vitro Cellular and Developmental Biology - Plant 47:710-718.

Vispute, S., and Khopade, A. 2011. Glycyrrhiza glabra Linn. - "Klitaka": A review. International Journal of Pharma and Bio Sciences 2:42-50.

Wongwicha, W., Tanaka, H., Shoyama, Y., Tuvshintogtokh, I., and Putalun, W. 2008. Production of glycyrrhizin in callus cultures of licorice. Zeitschrift fur Naturforschung C 63:413-417.

Yadav, K., and Singh, N. 2012. Factors influencing in vitro plant regeneration of liquorice (Glycyrrhiza glabra L.) Iranian Journal of Biotechnology 10:161-167. 